\title{
Assessment of Water Buffer Capacity of Two Morphometrically Different, Degraded, Urban Lakes
}

\author{
Jolanta Grochowska \\ Department of Water Protection Engineering and Environmental Microbiology, Faculty of Geoengineering, \\ University of Warmia and Mazury in Olsztyn, St. Prawocheńskiego 1, 10-720 Olsztyn, Poland; \\ jgroch@uwm.edu.pl
}

Received: 9 March 2020; Accepted: 20 May 2020; Published: 25 May 2020

\begin{abstract}
The research was conducted in Karczemne Lake (area, 40.4 ha; maximum (max.) depth, $3.2 \mathrm{~m}$ ) and Klasztorne Małe Lake (area, $13.7 \mathrm{ha}$; max. depth, $20.0 \mathrm{~m}$ ) located in the Kashubian Lake District (Northern Poland). From the beginning of the 1950s, these reservoirs have received municipal and storm wastewater. The long-term process of lake contamination has shaped the specific buffer capacity conditions and influenced the circulation of carbonate and bicarbonate in the water of these ecosystems. Extremely high concentrations of nutrients (Karczemne Lake: max. total phosphorous (TP) level, $7.5 \mathrm{mg} \mathrm{P} \mathrm{L}^{-1}$; max. total nitrogen (TN) level, $5.6 \mathrm{mg} \mathrm{N} \mathrm{L}^{-1}$; Klasztorne Małe Lake: max. TP level, $20.6 \mathrm{mg} \mathrm{P} \mathrm{L}^{-1}$; max. TN level, $43.3 \mathrm{mg} \mathrm{N} \mathrm{L}^{-1}$ ) have caused very intensive primary production processes (Karczemne Lake: max. chlorophyll-a level, $193.40 \mu^{g^{-3}}{ }^{-3}$ max. Secchi disc visibility, $0.85 \mathrm{~m}$; Klasztorne Małe Lake: max. chlorophyll-a level, $160.01 \mu \mathrm{g} \mathrm{m}^{-3}$; max. Secchi disc visibility, $1.15 \mathrm{~m}$ ). In the polymictic Karczemne Lake, the $\mathrm{pH}$ value of all water columns exceeded 10.0 (max. $\mathrm{pH}, 10.41$ ), and in the meromictic Klasztorne Małe Lake, the $\mathrm{pH}$ of the surface water layers oscillated around 9.5. In the polymictic Karczemne Lake, despite intensive photosynthesis, the calcium content and alkalinity were similar throughout the whole water column due to constant circulation. In the meromictic Klasztorne Małe Lake, during the growing season, a decrease in calcium concentration and alkalinity of the surface water layers and an increase in calcium concentration at the bottom were noted.
\end{abstract}

Keywords: degraded urban lake; buffer capacity; alkalinity; total hardness

\section{Introduction}

The contamination of freshwater with a wide range of pollutants has become a global problem over the past hundred years [1-3]. At the turn of the century, the development of industries has affected surface water pollution. Numerous types of human interventions have imposed a negative impact on water quality and ecological state [4-6]. Many pollutants have reached natural water through urbanization, industrialization, and agricultural use of areas near water reservoirs. The inflow of pollutants with a high content of nutrients and organic compounds has accelerated eutrophication or caused rapid degradation of water reservoirs. Urban lakes are particularly endangered because they receive water from municipal, industrial, and precipitation waste treatments [7-10]. The untreated wastewater flowing into lakes is particularly dangerous for these ecosystems because it transports a very high load of nutrients and organic matter [11,12]. Excessive nutrient loads contribute to the violation of the existing natural ecosystem balance and increase the intensity of primary production. The increase in organic matter usually leads to disturbances of oxygen settings and sometimes even to complete deoxygenation of the environment due to algal growth and organic matter decomposition [13]. The occurrence of oxygen loss in water overlaying bottom sediments during stagnation periods leads to 
a decrease in the redox potential and consequently to the release of reduced ions from these sediments to the near-bottom water [14].

According to Kremleva and Moiseenko [15] and Lacoul et al. [16], one of the pressing global problems is the acidification of natural water bodies. An increase in the acidity of natural waters impacts various components of aquatic ecosystems, such as the modification of the geochemical cycles of elements and enhancement of the concentrations of heavy metals by transforming them into the most toxic species [17-19], thus causing various adverse biological effects. Surface water ecosystems can neutralize the acid supply due to their buffer capacity. The buffer capacity of natural water is determined by the soil and bedrock through which it flows. The main sources for the natural buffer capacity are rocks that contain carbonate, bicarbonate, and hydroxide compounds. Borates, silicates, and phosphates may also contribute to alkalinity. Limestone is rich in carbonates, and water flowing through limestone regions or bedrock containing carbonates generally has a high alkalinity (a good buffering capacity) [20-22]. Areas rich in granites and some conglomerates and sandstones may exhibit a low alkalinity and, therefore, a poor buffering capacity [23]. Pollution introduced to surface waters can also change the buffer capacity. Depending on the nature and composition of the wastewater released into surface waters, it may increase or decrease the water buffer capacity. If the wastewater is acidic (e.g., industrial wastewater), then the water $\mathrm{pH}$ is reduced. In contrast, municipal wastewater usually contains large amounts of calcium and bicarbonate, thus causing an increase in the content of these components in the receiving water $[5,13]$.

The presence of calcium carbonate or other compounds, such as magnesium carbonate, contributes carbonate ions to the buffering system. The buffer capacity is also related to hardness because the main source of alkalinity is usually carbonate rocks (limestone), which mostly consist of $\mathrm{CaCO}_{3}$. If $\mathrm{CaCO}_{3}$ actually accounts for most of the alkalinity, the hardness in $\mathrm{CaCO}_{3}$ is equal to the alkalinity. Since hard water contains metal carbonates (mostly $\mathrm{CaCO}_{3}$ ), it is high in alkalinity. Conversely, unless carbonate is associated with sodium or potassium, which do not contribute to hardness, soft water usually has a low alkalinity and a poor buffering capacity [24]. A high buffer capacity is important for fish and aquatic life because it protects or buffers against rapid $\mathrm{pH}$ changes. Living organisms, especially aquatic organisms, function optimally in the $\mathrm{pH}$ range from 6.0 to 9.0. In the available literature [25-30], acid shock may occur in spring due to acid snow melting, thunderstorms, discharge of tannic water, acid rain, acidic dryfall, and other discharges entering streams. If increasing amounts of acids enter a water body, the water buffering capacity is consumed. If additional buffering material can be obtained from surrounding soils and rocks, the alkalinity level may eventually be restored. However, a temporary loss of the buffer capacity allows $\mathrm{pH}$ levels to drop to those harmful to aquatic life.

It can be assumed that the sewage discharged into surface waters may affect the buffer capacity because it contains various chemicals, including calcium, chlorides, heavy metals (copper, zinc, and lead) and polycyclic aromatic hydrocarbons (PAHs). In the literature, there are no previous studies examining the influence of long-term sewage discharge on the indicators determining the buffer properties of lake water.

The buffer capacity of water is one of the most important variables in water quality assessment. This water property influences many biological and chemical processes in water reservoirs. It is known that, due to the buffering presence of calcium carbonates, bicarbonates, and hydroxides, a fixed $\mathrm{pH}$ level is maintained in lakes, which after the transient changes caused, for example, by the input of pollutants, returns to its previous level. This is very important because aquatic organisms require a stable $\mathrm{pH}$ within the optimal range. It is proposed that in the case of monitoring a lake, which is a stormwater and sanitary wastewater receiver, it is very important to examine the water buffer capacity properties because they may change as a result of additional amounts of calcium and magnesium due to sewage inflow. In addition, the $\mathrm{pH}$ should be controlled.

The aim of this study was to determine the changes in buffer capacity indicators ( $\mathrm{pH}$, alkalinity, total hardness, and calcium and magnesium contents) as an effect of long-term sewage discharge 
into two morphometrically different, degraded, urban lakes—the polymictic Karczemne Lake and the meromictic Klasztorne Małe Lake.

\section{Material and Methods}

\subsection{Study Site}

Examples of extremely long-term degraded water ecosystems are the Karczemne and Klasztorne Małe lakes in Kartuzy town (Eastern Pomeranian District, Poland). From the early 1950s, these lakes have been transformed into sewage receivers for domestic sewage, as well as sewage from dairies, slaughterhouses, breweries, furniture factories, and municipal hospitals. Over 30 years, $60 \%$ of the raw municipal sewage entered Karczemne Lake through six sanitary sewers, and the remainder entered Klasztorne Małe Lake via three sanitary collectors. With the expansion of the urban area, the amount of municipal sewage increased. Impurities from emerging single-family housing were collected in leaking cesspits, causing some of the pollution to seep into the ground and migrate toward the lakes. Cesspits experienced overflows to the combined sewerage network, and municipal sewage directly reached the lakes in this way. It was also possible to illegally connect the sanitary sewage from individual domestic properties to the stormwater drainage system and directly discharge sewage to the lakes from homes located on their shores. The improvement of water and sewage management in Kartuzy city began in the mid-1970s. In 1982, a mechanical-biological sewage treatment plant was launched. In the 1990s, almost the entire city was connected to a sanitary sewerage system, and it was only in 2010 that the management of stormwater was organized by building settling tanks and stormwater separators. Until 2018, the stormwater drainage network in Kartuzy covered only part of the city (17\%). This situation meant that during heavy rainfall, local flooding occurred, and the excess rainwater and snowmelt from streets with no rainwater drainage system entered the sanitary sewerage system, thus overloading it. The connection of the existing stormwater drainage system to the sanitary sewerage system caused raw sewage loading into the lakes.

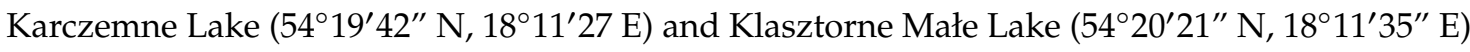
are part of the river-lake network in which the natural outflow of water occurs in the following direction: Lake Mielenko-Lake Karczemne-Lake Klasztorne Małe-Lake Klasztorne Duże-Klasztorna Struga-Słupinia-Radunia-Motława-Baltic Sea. Karczemne and Klasztorne Małe lakes are strongly degraded, urban reservoirs located in the Kashubian Lake District and belong to the macroregion of the Eastern Pomeranian District in Kartuzy town (Figure 1) [31].
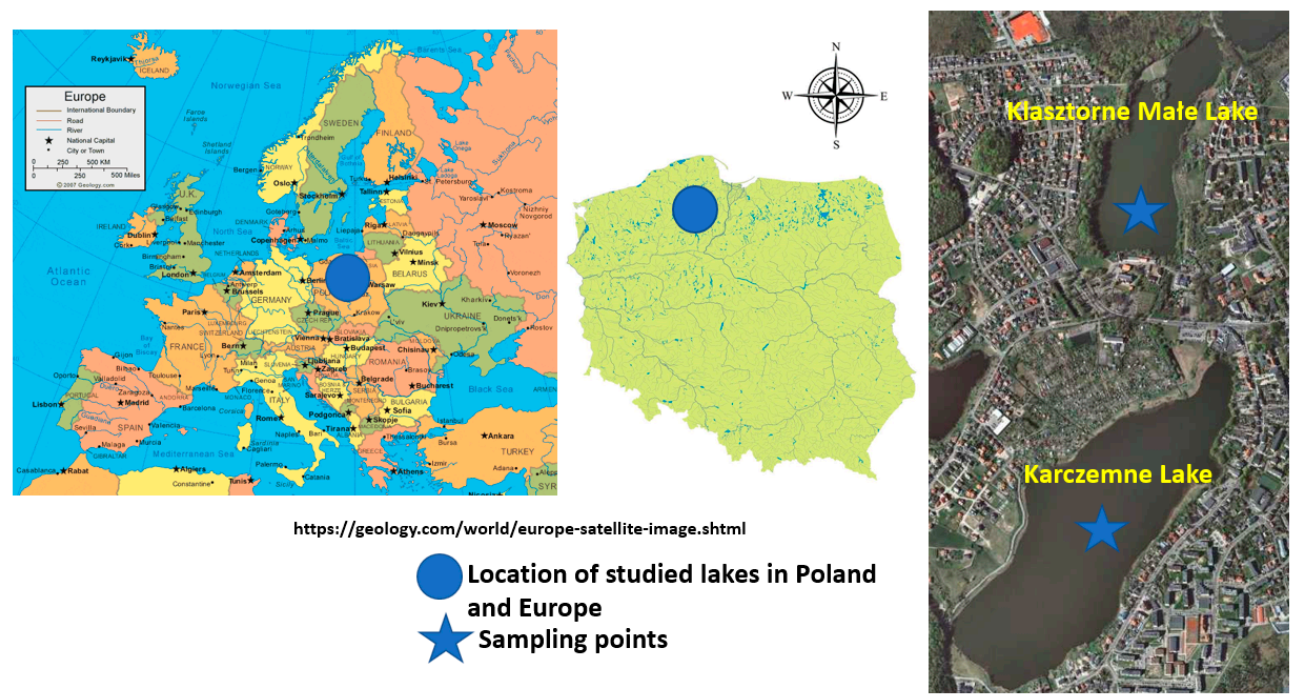

Figure 1. Research area location of Karczemne and Klasztorne Małe lakes. 
Karczemne Lake is a shallow, polymictic lake. The basin of the lake is semicircular (depth index (DI), 0.62; calculated as the ratio of the mean depth to the maximum depth, and this ratio reflects the shape of the lake bowl and geometrically controls the proximity to solids) and poorly seated in the ground, which is indicated by its relative depth of 0.0050 (the relative depth is calculated as the ratio of the maximum depth to the square root of the lake surface). This parameter indicates the degree of sinking of the lake bowl in the ground. Shallow and large lakes have a low relative depth, while deep lakes have high values. Its area is 40.4 ha and its maximum depth is $3.2 \mathrm{~m}$ (Table 1). The total catchment basin of Karczemne Lake covers $5.15 \mathrm{~km}^{2}$. This area is covered by two entirely different (in their ability to activate the load of nutrients in surface flow) forms of land usage: forests and urbanized areas. The direct catchment of Karczemne Lake, excluding the area covered by the drainage system collecting rainwater, covers $0.45 \mathrm{~km}^{2}$; wasteland constitutes $20.7 \%$ of its total surface area and forests grow over the other $79.3 \%$.

Table 1. Morphometric parameters of Karczemne and Klasztorne Małe lakes.

\begin{tabular}{ccc}
\hline Parameter & Karczemne & Klasztorne Małe \\
\hline Geographical coordinates & $54^{\circ} 19^{\prime} 42^{\prime \prime} \mathrm{N}, 18^{\circ} 11^{\prime} 27^{\prime \prime} \mathrm{E}$ & $54^{\circ} 20^{\prime} 21^{\prime \prime} \mathrm{N}, 18^{\circ} 11^{\prime} 35^{\prime \prime} \mathrm{E}$ \\
Height above mean sea level (m a. s. 1.) & 207.3 & 203.0 \\
Lake surface (ha) & 40.4 & 13.7 \\
Maximum depth (m) & 3.2 & 20.0 \\
Average depth (m) & 1.98 & 8.1 \\
Relative depth & 0.0050 & 0.054 \\
Depth indicator & 0.62 & 0.40 \\
Volume (in thousand $\mathrm{m}^{3}$ ) & 798.3 & 1106.0 \\
Maximum length (m) & 1282 & 720 \\
Maximum width (m) & 445 & 250 \\
Average width (m) & 315 & 190 \\
Elongation indicator & 2.9 & 2.9 \\
Coastline length (m) & 3163 & 1850 \\
Shoreline expansion indicator & 1.4 & 1.4 \\
\hline
\end{tabular}

According to Januszkiewicz and Jakubowska [32], the daily load of the biological oxygen demand (BOD) introduced in Karczemne Lake amounts to $354 \mathrm{~kg} \mathrm{O}_{2}$, while the total nitrogen level is $120 \mathrm{~kg}$.

In 2013, regarding the inflow of nutrients to Karczemne Lake, the catchment and atmospheric sources comprised the following basic components: diffuse sources, inflow of water via the watercourse linking Karczemne Lake with Mielenko Lake (this watercourse flows into the reservoir in the central part of the west shore), point sources ( 6 collectors of the rain drainage system), atmospheric sources, and recreation (i.e., angling). The total load of phosphorus introduced into Lake Karczemne was $161.7 \mathrm{~kg} \mathrm{P}_{\text {year }}{ }^{-1}\left(0.400 \mathrm{~g} \mathrm{P} \mathrm{m}^{-2}\right.$ year $\left.{ }^{-1}\right)$, while that of nitrogen reached $1333.9 \mathrm{~kg} \mathrm{~N}_{\text {year }}{ }^{-1}$ (3.30 $\mathrm{g} \mathrm{N} \mathrm{m}^{-2}$ year $^{-1}$ ) [33]. In 2019, the load of biogenic pollutants introduced into the lake was lower due to the reconstruction and extension of the sewerage network of Kartuzy city and amounted to $112.6 \mathrm{~kg} \mathrm{P}_{\text {year }}{ }^{-1}\left(0.279 \mathrm{~g} \mathrm{P} \mathrm{m}^{-2}\right.$ year $\left.^{-1}\right)$ and $903.8 \mathrm{~kg} \mathrm{~N}$ year $^{-1}\left(2.237 \mathrm{~g} \mathrm{~N} \mathrm{~m}^{-2}\right.$ year $\left.^{-1}\right)$.

Klasztorne Małe Lake is a glacial lake with the characteristics of a ribbon lake. The longer axis runs from the southwest to the northeast (SW-NE). Its area is 13.7 ha. Morphologically, this is a single-basin lake with a distinguishable sink basin. The basin with a shape resembling a paraboloid (DI, 0.4) is deeply seated in the ground (relative depth, 0.054) (Table 1). Klasztorne Małe Lake is a dimictic lake belonging to the bradymictic subgroup, in which water mixing is difficult because of the disadvantageous morphometric conditions. Currently, the water mixing conditions in the lake are extremely unfavorable due to the long-term sewage supply. Klasztorne Małe Lake is subject to meromictic stratification, with the mixolimnion reaching a maximum of $14 \mathrm{~m}$ in depth and a monimolimnion below. 
Klasztorne Małe Lake was subjected to two restoration procedures-hypolimnetic aeration in 1986 and phosphorus inactivation with Phoslock ${ }^{\circledR}$ (La-modified bentonite) and iron coagulant PIX in 2006 [34].

The total catchment basin of Klasztorne Małe Lake covers $7.45 \mathrm{~km}^{2}$, and the direct catchment covers $13.0 \mathrm{ha}$. The latter is the actual surface, excluding the area of the rain drainage system. The area of the direct reservoir supply is entirely covered by mixed forests. According to Januszkiewicz and Jakubowska [32], the daily BOD load introduced into Klasztorne Małe Lake amounted to $177 \mathrm{~kg} \mathrm{O}_{2}$ and the total nitrogen load was $56 \mathrm{~kg} \mathrm{~N}$. The wastewater discharged into the lake is characterized by a turbid gray, sometimes brown-bloody color, abundant suspension, and odor.

In 2013, Klasztorne Małe Lake was supplied from diffuse sources, surface inflow (the mouth of the Klasztorna Struga), point sources (10 collectors of the rain drainage system), atmospheric sources, and recreation, namely, angling. The total phosphorus load introduced into Klasztorne Małe Lake was $516.8 \mathrm{~kg} \mathrm{P}_{\text {year }}{ }^{-1}$ ( $3.772 \mathrm{~g} \mathrm{P} \mathrm{m}^{-2}$ year $^{-1}$ ), whereas that of nitrogen was $1571.5 \mathrm{~kg} \mathrm{~N}_{\text {year }}{ }^{-1}$ (11.471 $\mathrm{g} \mathrm{N} \mathrm{m}^{-2}$ year $\left.^{-1}\right)$ [33].

In 2019, after modernization of the city's sewerage system, the nutrient load introduced into the lake decreased and reached $365.6 \mathrm{~kg} \mathrm{P}$ year ${ }^{-1}\left(2.669 \mathrm{~g} \mathrm{P} \mathrm{m}^{-2}\right.$ year $\left.^{-1}\right)$ and $1221.2 \mathrm{~kg} \mathrm{~N}_{\text {year }}{ }^{-1}$ $\left(8.914 \mathrm{~g} \mathrm{~N} \mathrm{~m}^{-2}\right.$ year $\left.^{-1}\right)$.

\subsection{Water Sample Collection and Analysis}

Water samples were collected at one-month intervals over the period from April to November in 2013 and 2019. The results for 1957 were obtained from the work of Januszkiewicz and Jakubowska [32].

The laboratory analyses of the aquatic chemical parameters, selected according to the method presented by Withanachchi et al. (2018) [35] (pH, alkalinity, total hardness, calcium, and magnesium), were performed on the samples collected from the deepest part of the lakes $(1 \mathrm{~m}$ below the water surface and $1 \mathrm{~m}$ above the bottom) (Figure 1). Samples were collected with a standard water sampler. The $\mathrm{pH}$ was determined with a ProDSS 4-port Digital Sampling System (YSI). The calcium content, total hardness, and alkalinity were measured by the titration method. The calcium content and total hardness were determined with EDTA, and alkalinity was measured with an $\mathrm{HCl}$ solution and methyl orange indicator. All analyses were performed in triplicate. The chemical analyses of water were performed in accordance with standard methods [36] and the methodology of Hermanowicz et al. [37]. In addition, the total phosphorus, total nitrogen, $\mathrm{BOD}_{5}$ (organic matter), and chlorophyll levels were measured in the water samples collected in 2013 and 2019, according to the methodology of Hermanowicz et al. [37]. During each sampling in the field, the water transparency in the lakes was measured by the Secchi disc visibility.

The data were statistically analyzed (basic statistics-mean value, standard deviation, and one-way ANOVA; $p=0.05$ ) with the Statistical 13.0 software package [38]. The alternatively tested hypothesis was the presence of significant differences in the mean values of $\mathrm{pH}$, alkalinity, total hardness, and calcium and magnesium contents between the different years of domestic sewage inflow (1957), after decreasing domestic sewage inflow (2013), and after stopping domestic sewage inflow (2019). The data were analyzed with Excel (2013), and Google Maps was applied to map the study area.

\section{Results}

The statistical analysis of the obtained results showed that the long-term municipal sewage discharge to the lakes caused highly significant differences $(\alpha<0.05)$ in $\mathrm{pH}$ values between the polymictic (Karczemne Lake) and meromictic (Klasztorne Małe Lake) lakes (Table 2). In 1957, the pH of the surface water layers of Karczemne Lake ranged from 8.05 to 8.72 (the average value fluctuated around $8.31 \pm 0.237$ ), while that of the surface water layers of Klasztorne Małe Lake ranged from 7.10 to 8.50 (an average value of $7.97 \pm 0.455$ ) (Figures 2 and 3). In both lakes, maximum values were noted in June. 
Table 2. Results of one-way ANOVA analyses for investigated variables in the water of Karczemne and Klasztorne Małe lakes.

\begin{tabular}{ccccc}
\hline \multirow{2}{*}{ Variable } & \multicolumn{2}{c}{ Karczemne Lake } & \multicolumn{2}{c}{ Klasztorne Male Lake } \\
\cline { 2 - 5 } & $\boldsymbol{F}$ Value & $\boldsymbol{p}$ Value & $\boldsymbol{F}$ Value & $\boldsymbol{p}$ Value \\
\hline pH surface water & 17.10682 & 0.000039 & 15.32119 & 0.000079 \\
pH near-bottom water & 6.83552 & 0.005172 & 20.25271 & 0.000013 \\
Calcium surface water & 35.52678 & 0.000000 & 1.748816 & 0.198381 \\
Calcium near-bottom water & 2.69663 & 0.000006 & 0.782597 & 0.470102 \\
Magnesium surface water & 1.757427 & 0.196922 & 1.667998 & 0.212660 \\
Magnesium near-bottom water & 0.325444 & 0.725785 & 1.981087 & 0.162869 \\
Alkalinity surface water & 79.21411 & 0.000000 & 4.504244 & 0.023563 \\
Alkalinity near-bottom water & 71.6136 & 0.000000 & 4.484559 & 0.023891 \\
Total hardness surface water & 3.328399 & 0.055511 & 1.301817 & 0.293106 \\
Total hardness near-bottom water & 8.168011 & 0.002377 & 1.813760 & 0.187666 \\
\hline
\end{tabular}

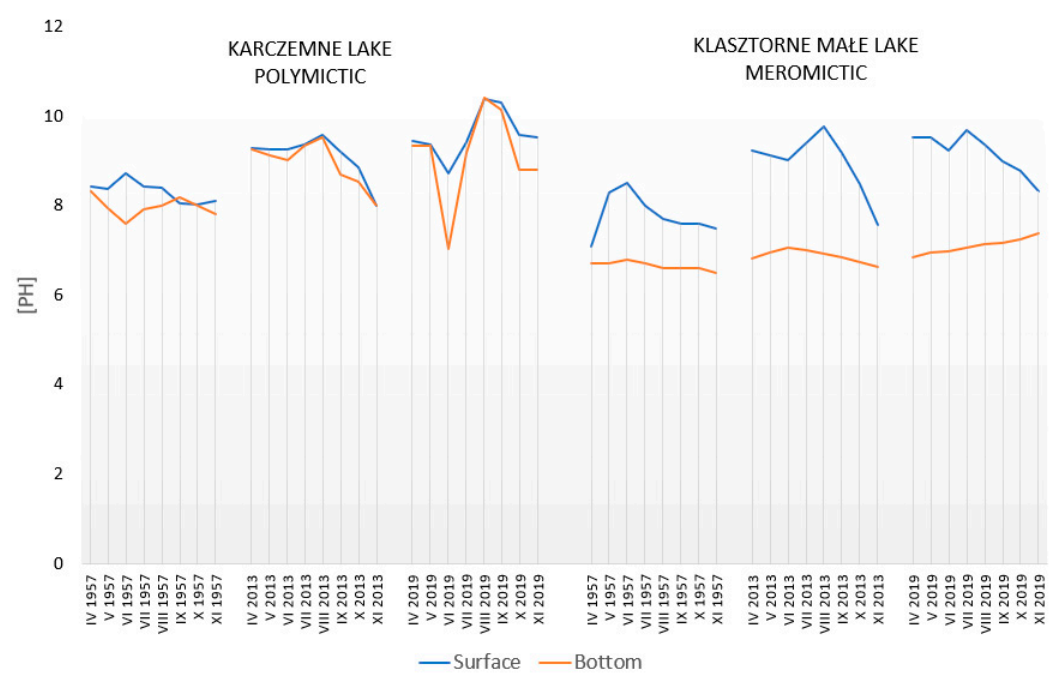

Figure 2. Changes in the $\mathrm{pH}$ value in the water of Karczemne and Klasztorne Małe lakes in selected research years.

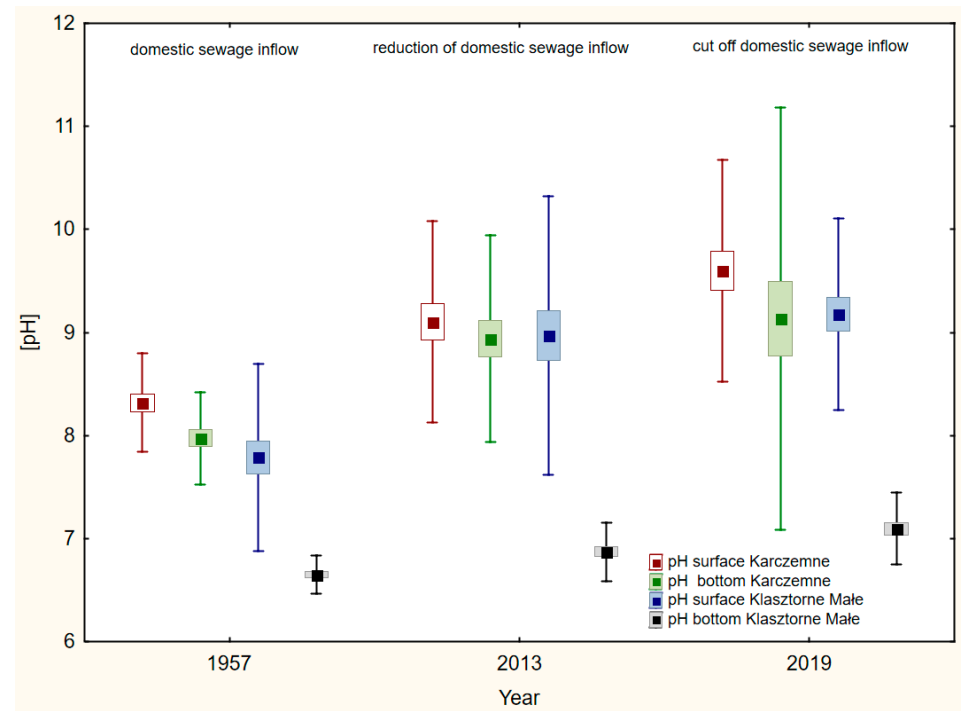

Figure 3. Mean annual values of $\mathrm{pH}$ (box \pm SEM; whisker plots $\pm \mathrm{SD}$ ) in the water of Karczemne and Klasztorne Małe lakes. 
In 1957, the $\mathrm{pH}$ of the bottom water layers of Karczemne Lake ranged from 7.81 to 8.32 (a mean value of $7.97 \pm 0.223$ ), and in Klasztorne Małe Lake, the $\mathrm{pH}$ of the bottom water layers ranged from 6.50 to 6.80 (a mean value of $6.65 \pm 0.092$ ) (Figures 2 and 3). In the subsequent research years, the $\mathrm{pH}$ values of the analyzed lakes increased. A particularly steep $\mathrm{pH}$ increase was observed in the polymictic Karczemne Lake. In 2019, the pH of the surface water layers of Karczemne Lake ranged from 9.37 to 10.41 (average $\mathrm{pH}, 9.59 \pm 0.536$ ). In the near-bottom water layers of the reservoir, the $\mathrm{pH}$ was slightly lower and ranged from 8.81 to 10.41 (average $\mathrm{pH}, 9.37 \pm 1.020$ ) (Figures 2 and 3). In 2019, in the surface water layers of the meromictic Klasztorne Małe Lake, the $\mathrm{pH}$ value ranged from 8.31 to 9.70 (average $\mathrm{pH}, 9.17 \pm 0.465$ ), and in the near-bottom water layers, the $\mathrm{pH}$ varied between 6.85 and 7.38 (average $\mathrm{pH}, 7.09 \pm 0.140$ ) (Figures 2 and 3). Over 60 years, the $\mathrm{pH}$ of the surface layers of Karczemne Lake increased by $15 \%$, and that of the bottom layers increased by $17 \%$. In turn, in the surface waters of Klasztorne Małe Lake, the water $\mathrm{pH}$ value increased by $15 \%$, while in the bottom layers, the water $\mathrm{pH}$ value increased by $7 \%$.

The statistical analysis of the results revealed that the municipal sewage discharge resulted in a significant change $(\alpha<0.05)$ in the calcium content of the water of the polymictic Karczemne Lake, but it did not cause a significant change in the magnesium content of the water of both the analyzed lakes (polymictic and meromictic) and in the calcium content of the water of Klasztorne Małe Lake (meromictic) (Table 2). In all research years (domestic sewage inflow, after decreasing domestic sewage inflow, and after stopping domestic sewage inflow), the calcium content throughout the water column of Karczemne Lake ranged from 35.1 to $47.3 \mathrm{mg} \mathrm{Ca} \mathrm{L}^{-1}$, and its average value fluctuated around $41.6 \pm 2.34 \mathrm{mg} \mathrm{Ca} \mathrm{L}^{-1}$ (Figures 4 and 5). In the period of 1957-2019, throughout the entire water column of Klasztorne Małe Lake, the calcium content varied between 25.0 and $53.7 \mathrm{mg} \mathrm{Ca} \mathrm{L}^{-1}$ (the mean value oscillated around $42.4 \pm 2.2 \mathrm{mg} \mathrm{Ca} \mathrm{L}^{-1}$,) (Figures 4 and 5).

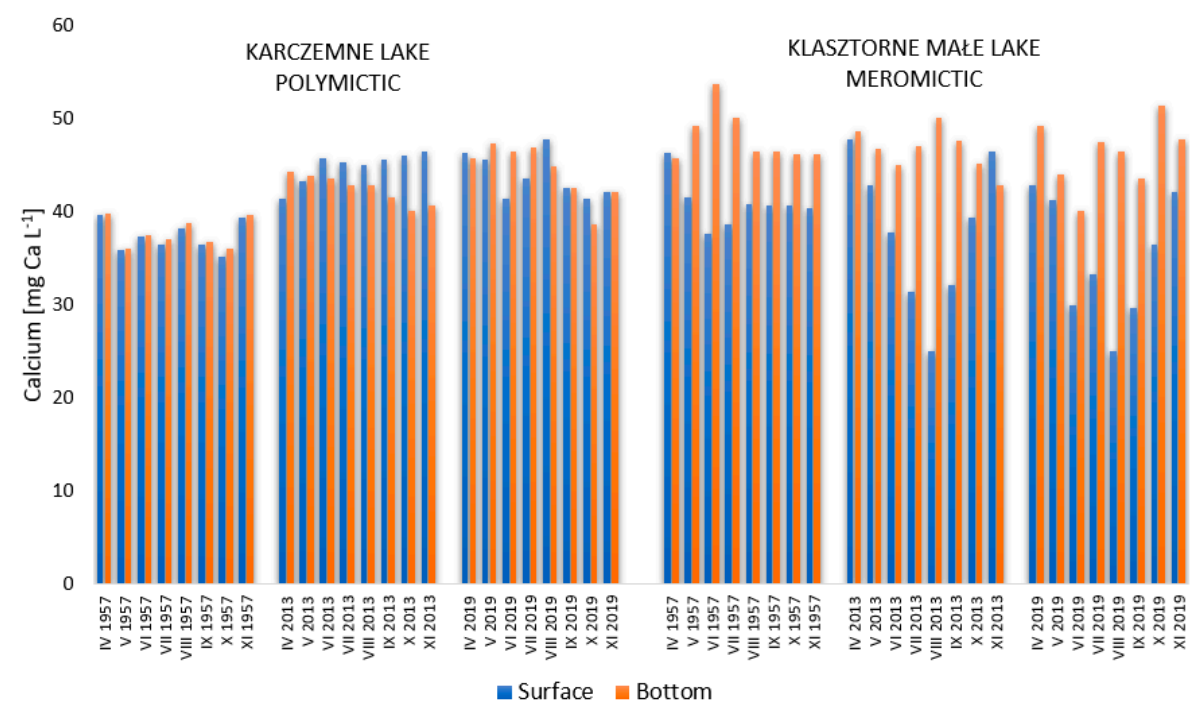

Figure 4. Changes in calcium content in the water of Karczemne and Klasztorne Małe lakes in selected research years. 


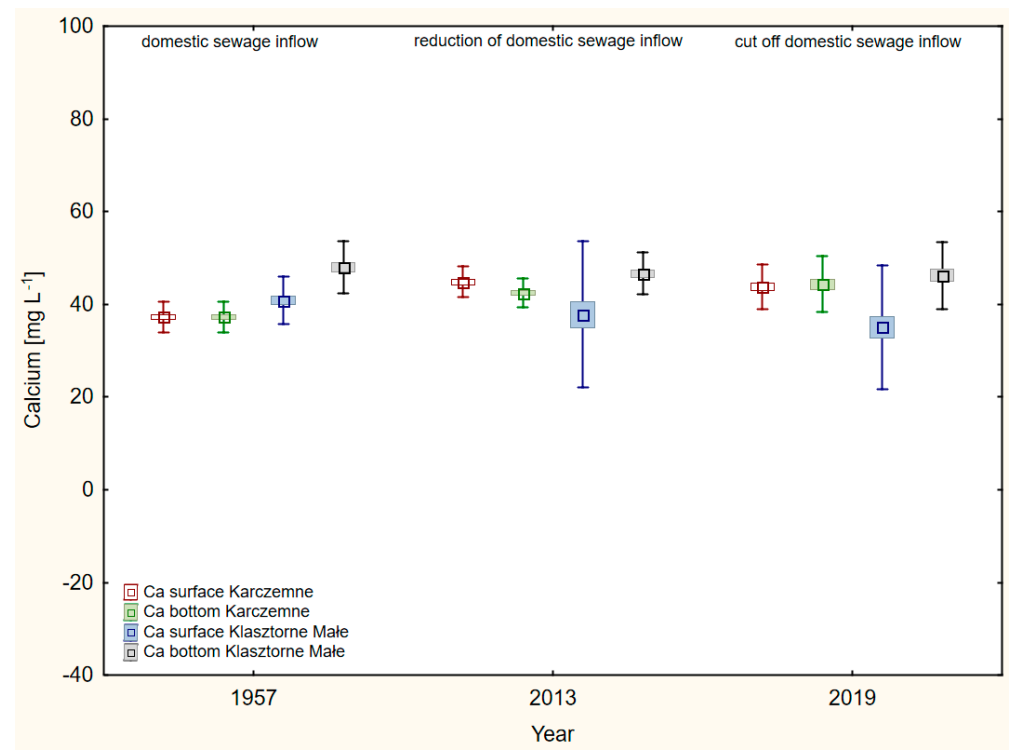

Figure 5. Mean annual values of calcium content (box \pm SEM; whisker plots $\pm S D$ ) in the water of Karczemne and Klasztorne Małe lakes.

In all research years (domestic sewage inflow, after decreasing domestic sewage inflow, and after stopping domestic sewage inflow), the magnesium content throughout the water column of Karczemne Lake ranged from 0.8 to $44.0 \mathrm{mg} \mathrm{Mg} \mathrm{L}^{-1}$, and its average value fluctuated around $5.86 \pm 4.36 \mathrm{mg} \mathrm{Mg} \mathrm{L}^{-1}$ (Figures 6 and 7). In the research years from 1957 to 2019, throughout the entire water volume of Klasztorne Małe Lake, the magnesium content varied between 2.8 and $81.5 \mathrm{mg} \mathrm{Mg} \mathrm{L}^{-1}$ (mean value, $13.8 \pm 9.52 \mathrm{mg} \mathrm{Mg} \mathrm{L}^{-1}$ ) (Figures 6 and 7).

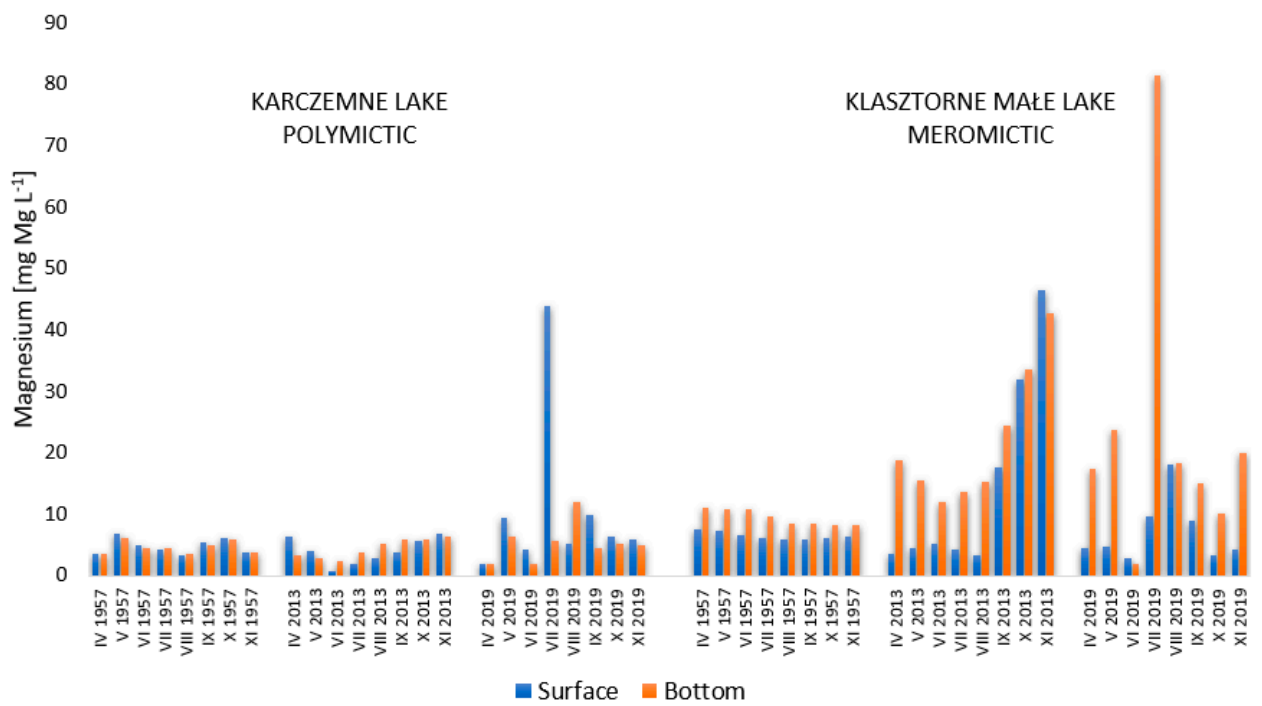

Figure 6. Changes in magnesium content in the water of Karczemne and Klasztorne Małe lakes in selected research years. 


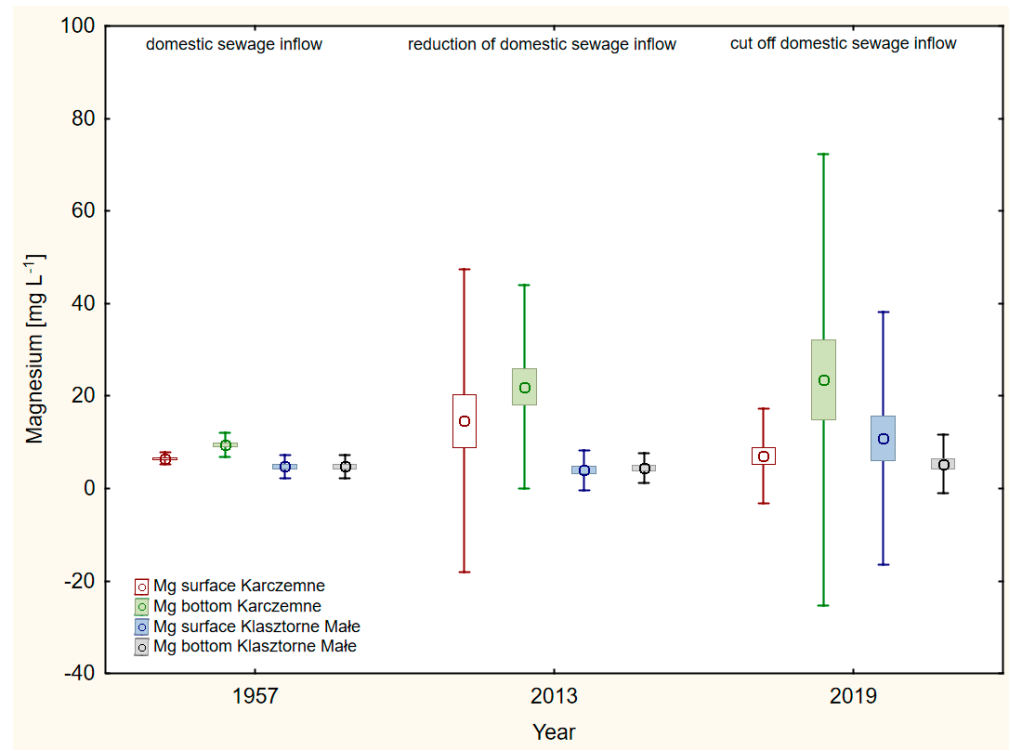

Figure 7. Mean annual values of magnesium content (box \pm SEM; whisker plots $\pm S D$ ) in the water of Karczemne and Klasztorne Małe lakes.

The statistical analysis indicated that the long-term discharge of domestic sewage significantly influenced $(\alpha<0.05)$ the alkalinity throughout the whole water volume of the morphometrically different lakes (Table 2).

In the year with domestic sewage inflow (1957), throughout the entire water column of the polymictic Karczemne Lake, the alkalinity remained the same. The average water alkalinity was $1.83 \pm 0.150 \mathrm{mval} \mathrm{L}^{-1}$ (Figures 8 and 9). After 60 years of domestic sewage inflow, the alkalinity of the water of Karczemne Lake increased almost twice (2019). The average alkalinity values were similar between the surface water layer $\left(2.74 \pm 0.212 \mathrm{mval} \mathrm{L}^{-1}\right)$ and the near-bottom water layer $\left(2.81 \pm 0.236 \mathrm{mval} \mathrm{L}^{-1}\right)$ (Figures 8 and 9).

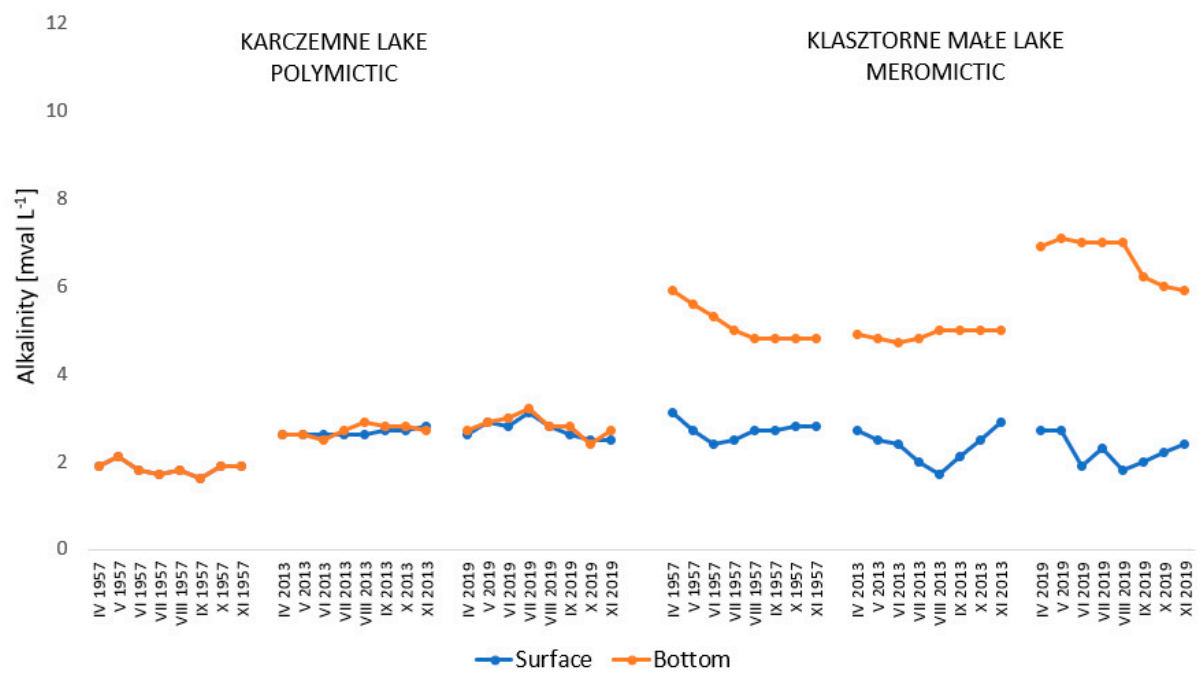

Figure 8. Changes in alkalinity values in the water of Karczemne and Klasztorne Małe lakes in selected research years. 


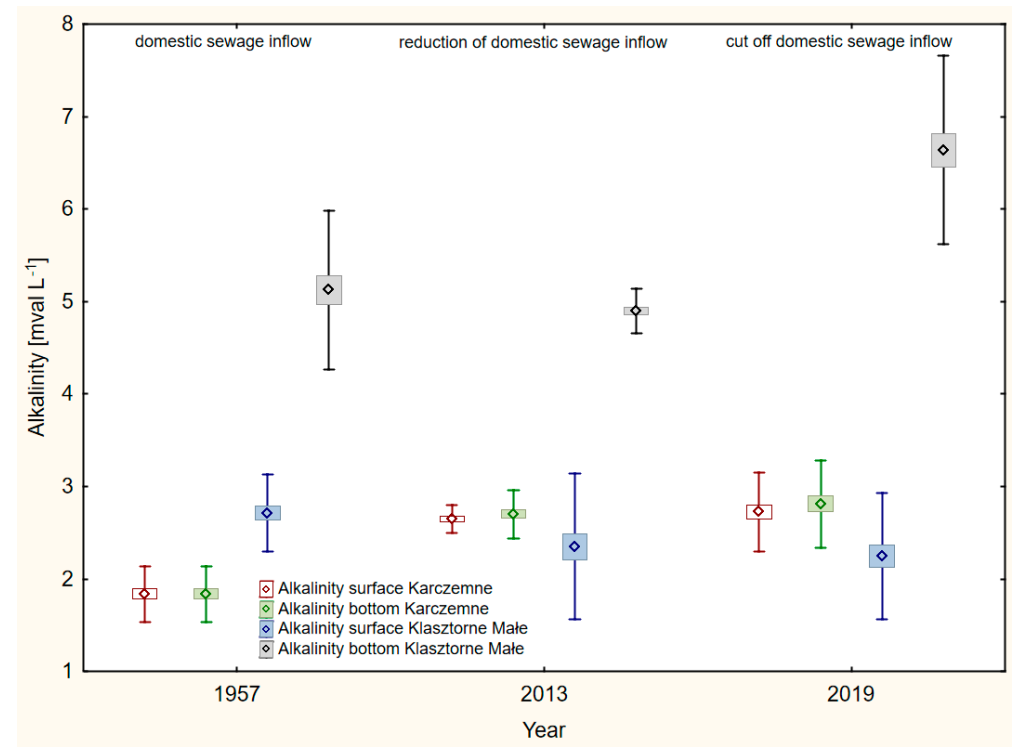

Figure 9. Mean annual values of alkalinity (box \pm SEM; whisker plots \pm SD) in the water of Karczemne and Klasztorne Małe lakes.

In the meromictic Klasztorne Małe Lake, in the first year when municipal sewage was discharged, vertical alkalinity stratification was noted with an increase in alkalinity toward the bottom (Figure 8). The average alkalinity of the surface water layer was $2.71 \pm 0.210 \mathrm{mval} \mathrm{L}^{-1}$, while that of the near-bottom water layers was $5.12 \pm 0.430 \mathrm{mval} \mathrm{L}^{-1}$ (Figure 9). In 2019, after 60 years of discharging wastewater to Klasztorne Małe Lake, a slight decrease in alkalinity was found in the surface water layer and an increase in alkalinity was found in the bottom water layers. As a result, clearer vertical alkalinity stratification occurred. In the surface water layer, the average alkalinity oscillated around $2.25 \pm 0.342 \mathrm{mval} \mathrm{L}^{-1}$, and in the bottom water layers, it oscillated around $6.63 \pm 0.509 \mathrm{mval} \mathrm{L}^{-1}$ (Figures 8 and 9).

The statistical analysis of the results revealed that municipal sewage discharge did not cause significant changes in the total hardness of the surface water layers of the polymictic Karczemne Lake or throughout the entire water column of the meromictic Klasztorne Małe Lake (Table 2). Statistically significant changes $(\alpha<0.05)$ in the total hardness were recorded in the near-bottom water layers of the shallow, polymictic Karczemne Lake (Table 2).

In 1957 (domestic sewage inflow), the total hardness throughout the water column of Karczemne Lake varied from 1.8 to $2.7 \mathrm{mval} \mathrm{L}^{-1}$, and its average value fluctuated around $2.2 \pm 0.342 \mathrm{mval} \mathrm{L}^{-1}$ (Figures 10 and 11). In the period from 2013 to 2019, in the surface water layer of the lake, the total hardness varied between 2.4 and $6.1 \mathrm{mval} \mathrm{L}^{-1}$ (average value, $2.88 \pm 0.694 \mathrm{mval} \mathrm{L}^{-1}$ ), and in the near-bottom water slayer, the total hardness ranged from 2.3 to 3.3 mval L$^{-1}$ (mean value, $2.620 \pm 0.225 \mathrm{mval} \mathrm{L}^{-1}$ ) (Figures 10 and 11).

In 1957 (domestic sewage inflow), the total hardness throughout the water column of the meromictic Klasztorne Małe Lake varied from 2.4 to $3.6 \mathrm{mval} \mathrm{L}^{-1}$, and its average value fluctuated around $2.86 \pm 0.199 \mathrm{mval} \mathrm{L}^{-1}$ (Figures 10 and 11). In the period from 2013 to 2019, in the surface water layer of the lake, the total hardness varied between 1.0 and $2.8 \mathrm{mval} \mathrm{L}^{-1}$ (average value, $2.25 \pm 0.503 \mathrm{mval} \mathrm{L}^{-1}$ ), while in the near-bottom water layer, it ranged from 2.1 to $9.6 \mathrm{mval} \mathrm{L}^{-1}$ (mean value, $4.030 \pm 1.238 \mathrm{mval} \mathrm{L}^{-1}$ ) (Figures 10 and 11). 


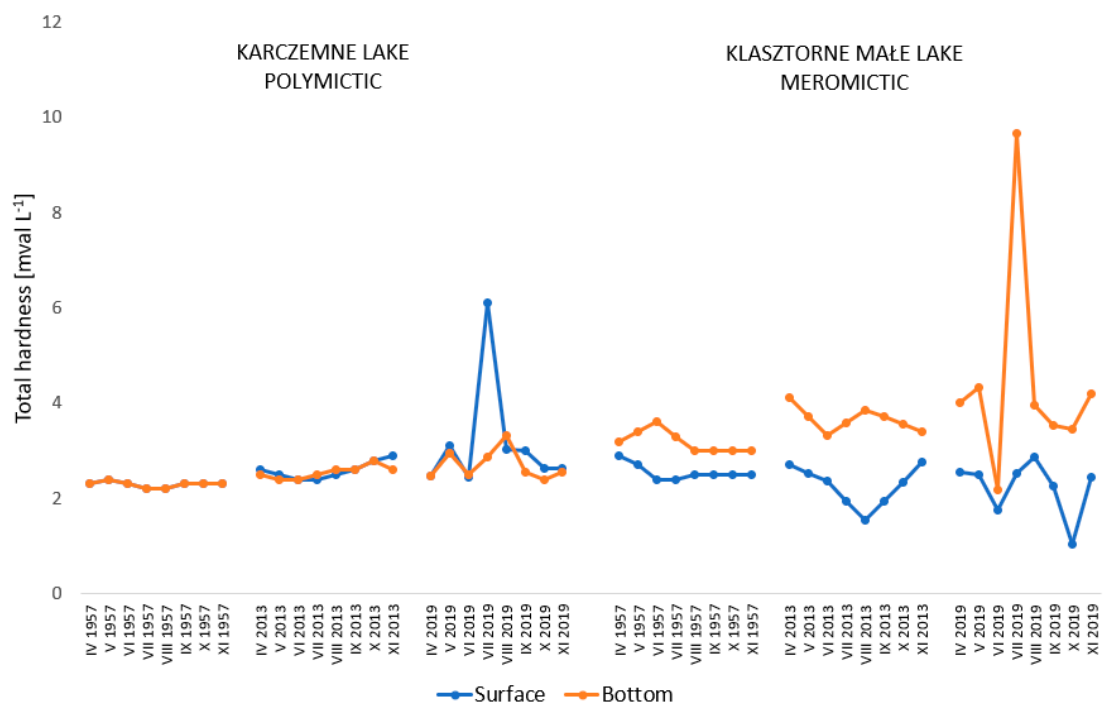

Figure 10. Changes in total hardness values in the water of Karczemne and Klasztorne Małe lakes in selected research years.

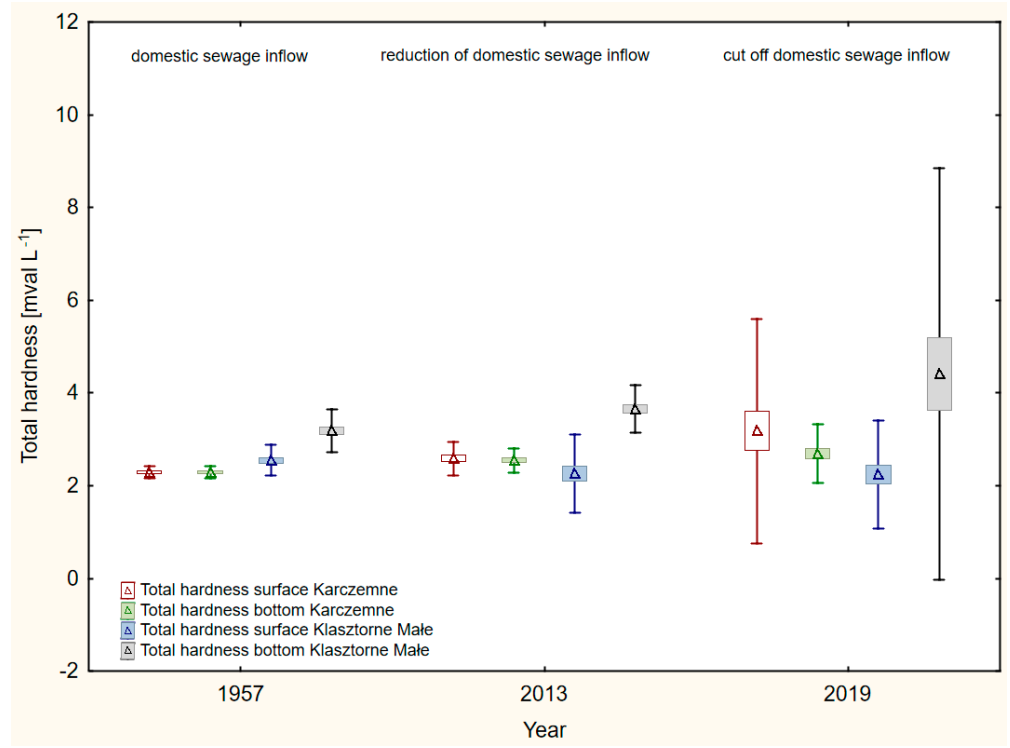

Figure 11. Mean annual values of total hardness (box \pm SEM; whisker plots \pm SD) in the water of Karczemne and Klasztorne Małe lakes.

In 2013, the average total phosphorus (TP) concentration in the surface water layer of Karczemne Lake was $0.85 \pm 0.13 \mathrm{mg} \mathrm{P} \mathrm{L}^{-1}$, and in the near-bottom layer, it was $2.87 \pm 2.49 \mathrm{mg} \mathrm{P} \mathrm{L}^{-1}$. In Klasztorne Małe Lake, the mean total phosphorus concentration in the surface water layer was $0.45 \pm 0.20 \mathrm{mg} \mathrm{P} \mathrm{L}^{-1}$, while at the bottom, it was $17.53 \pm 2.92 \mathrm{mg} \mathrm{P} \mathrm{L}^{-1}$ (Table 3). In 2019, in Karczemne Lake, the average total phosphorus concentration was $0.71 \pm 0.28 \mathrm{mg} \mathrm{P} \mathrm{L}^{-1}$ at the surface and $0.73 \pm 0.28 \mathrm{mg} \mathrm{P} \mathrm{L}^{-1}$ at the bottom (Table 3). In the meromictic Klasztorne Małe Lake, the average total phosphorus content in the surface water was $0.2 \pm 0.04 \mathrm{mg} \mathrm{P} \mathrm{L}^{-1}$, while at the bottom, it was $9.88 \pm 3.05 \mathrm{mg} \mathrm{P} \mathrm{L}^{-1}$ (Table 3). 
Table 3. Variability of nutrients, biological oxygen demand $\left(\mathrm{BOD}_{5}\right)$, chlorophyll-a, and Secchi disc visibility in study lakes.

\begin{tabular}{|c|c|c|c|c|c|}
\hline \multirow{2}{*}{ Parameter } & \multirow{2}{*}{ Unit } & \multicolumn{2}{|c|}{$\begin{array}{l}\text { Karczemne Lake } \\
\qquad 2013\end{array}$} & \multicolumn{2}{|c|}{$\begin{array}{l}\text { Klasztorne Małe Lake } \\
\qquad 2013\end{array}$} \\
\hline & & $\begin{array}{c}\text { Surface } \\
\text { Min-Max } \\
\text { Average/SD }\end{array}$ & $\begin{array}{c}\text { Bottom } \\
\text { Min-Max } \\
\text { Average/SD }\end{array}$ & $\begin{array}{c}\text { Surface } \\
\text { Min-Max } \\
\text { Average/SD }\end{array}$ & $\begin{array}{c}\text { Bottom } \\
\text { Min-Max } \\
\text { Average/SD }\end{array}$ \\
\hline Total phosphorus & $\mathrm{mg} \mathrm{PL}^{-1}$ & $\begin{array}{l}0.613-0.950 \\
0.849 / 0.138\end{array}$ & $\begin{array}{l}0.667-7.460 \\
2.871 / 2.489\end{array}$ & $\begin{array}{c}0.251-0.780 \\
0.446 / 0.205\end{array}$ & $\begin{array}{c}12.775-20.600 \\
17.528 / 2.920\end{array}$ \\
\hline Total nitrogen & $\operatorname{mg~N~L}{ }^{-1}$ & $\begin{array}{l}1.32-5.57 \\
3.05 / 1.56\end{array}$ & $\begin{array}{l}1.33-4.71 \\
2.85 / 1.21\end{array}$ & $\begin{array}{l}1.83-2.40 \\
2.02 / 0.23\end{array}$ & $\begin{array}{c}17.24-22.38 \\
19.77 / 2.34\end{array}$ \\
\hline $\mathrm{BOD}_{5}$ & $\mathrm{mg} \mathrm{O}_{2} \mathrm{~L}^{-1}$ & $\begin{array}{l}9.5-14.7 \\
11.5 / 2.4\end{array}$ & $\begin{array}{l}4.4-7.9 \\
5.8 / 1.6\end{array}$ & $\begin{array}{l}5.9-14.5 \\
9.6 / 3.6\end{array}$ & $\begin{array}{l}6.8-17.2 \\
10.7 / 4.5\end{array}$ \\
\hline Chlorophyll-a & $\mathrm{mg} \mathrm{m}^{-3}$ & $\begin{array}{c}26.62-95.13 \\
84.3 / 41.41\end{array}$ & - & $\begin{array}{l}28.6-64.47 \\
45.02 / 16.79\end{array}$ & - \\
\hline Secchi disc visibility & $\mathrm{m}$ & $\begin{array}{c}0.2-05 \\
0.3 / 0.15\end{array}$ & - & $\begin{array}{l}0.3-1.1 \\
0.6 / 0.3\end{array}$ & - \\
\hline \multirow[b]{2}{*}{ Parameter } & \multirow[b]{2}{*}{ Unit } & \multicolumn{2}{|c|}{$\begin{array}{c}\text { Karczemne Lake } \\
2019\end{array}$} & \multicolumn{2}{|c|}{$\begin{array}{l}\text { Klasztorne Małe Lake } \\
2019\end{array}$} \\
\hline & & $\begin{array}{c}\text { Surface } \\
\text { Min-Max } \\
\text { Average/SD }\end{array}$ & $\begin{array}{c}\text { Bottom } \\
\text { Min-Max } \\
\text { Average/SD }\end{array}$ & $\begin{array}{c}\text { Surface } \\
\text { Min-Max } \\
\text { Average/SD }\end{array}$ & $\begin{array}{c}\text { Bottom } \\
\text { Min-Max } \\
\text { Average/SD }\end{array}$ \\
\hline Total phosphorus & $\mathrm{mg} \mathrm{P} \mathrm{L}{ }^{-1}$ & $\begin{array}{l}0.360-1.220 \\
0.710 / 0.280\end{array}$ & $\begin{array}{c}0.381-1.280 \\
0.730 / 0.283\end{array}$ & $\begin{array}{l}0.165-0.321 \\
0.242 / 0.040\end{array}$ & $\begin{array}{c}7.014-15.625 \\
9.880 / 3.050\end{array}$ \\
\hline Total nitrogen & $\mathrm{mg} \mathrm{N} \mathrm{L}^{-1}$ & $\begin{array}{l}2.25-5.48 \\
3.16 / 0.91\end{array}$ & $\begin{array}{l}2.20-5.52 \\
3.08 / 0.99\end{array}$ & $\begin{array}{l}1.72-3.77 \\
2.35 / 0.29\end{array}$ & $\begin{array}{c}24.39-43.32 \\
37.64 / 6.59\end{array}$ \\
\hline $\mathrm{BOD}_{5}$ & $\mathrm{mg} \mathrm{O}_{2} \mathrm{~L}^{-1}$ & $\begin{array}{c}3.8-15.6 \\
7.0 / 3.6\end{array}$ & $\begin{array}{c}4.0-15.6 \\
7.2 / 3.8\end{array}$ & $\begin{array}{c}3.4-11.7 \\
7.7 / 2.8\end{array}$ & $\begin{array}{l}7.7-64.3 \\
41.0 / 21.0\end{array}$ \\
\hline Chlorophyll-a & $\mathrm{mg} \mathrm{m}^{-3}$ & $\begin{array}{l}56.67-170.92 \\
116.10 / 51.20\end{array}$ & - & $\begin{array}{c}27.80-160.00 \\
82.10 / 46.87\end{array}$ & - \\
\hline Secchi disc visibility & $\mathrm{m}$ & $\begin{array}{l}0.2-0.85 \\
0.35 / 0.2\end{array}$ & - & $\begin{array}{c}0.3-1.15 \\
0.6 / 0.3\end{array}$ & - \\
\hline
\end{tabular}

In 2013, the mean total nitrogen concentration in the surface water layer of Karczemne Lake was $3.0 \pm 1.56 \mathrm{mg} \mathrm{N} \mathrm{L}^{-1}$, and near the bottom, it was $2.85 \pm 1.21 \mathrm{mg} \mathrm{N} \mathrm{L}^{-1}$. In Klasztorne Małe Lake, the average total nitrogen (TN) concentration in the surface water layer was $2.02 \pm 0.23 \mathrm{mg} \mathrm{N} \mathrm{L}^{-1}$, while at the bottom, it was $19.77 \pm 2.33 \mathrm{mg} \mathrm{N} \mathrm{L}^{-1}$ (Table 3). In 2019, the average total nitrogen concentration in the water of Karczemne Lake was $3.0 \pm 1.0 \mathrm{mg} \mathrm{N} \mathrm{L}^{-1}$. In the surface water layer of Klasztorne Małe Lake, the mean TN was $2.35 \pm 0.29 \mathrm{mg} \mathrm{N} \mathrm{L}^{-1}$, while at the bottom, it was $37.64 \pm 6.59 \mathrm{mg} \mathrm{N} \mathrm{L}^{-1}$ (Table 3).

In 2013, the average $\mathrm{BOD}_{5}$ level in the surface water layer of Karczemne Lake was $11.4 \pm 2.4 \mathrm{mg}$ $\mathrm{O}_{2} \mathrm{~L}^{-1}$, and near the bottom, it was $5.8 \pm 1.6 \mathrm{mg} \mathrm{O}_{2} \mathrm{~L}^{-1}$. In Klasztorne Małe Lake, the average $\mathrm{BOD}_{5}$ level in the surface water layer was $9.6 \pm 3.6 \mathrm{mg} \mathrm{O}_{2} \mathrm{~L}^{-1}$, while it was $10.7 \pm 4.5 \mathrm{mg} \mathrm{O}_{2} \mathrm{~L}^{-1}$ at the bottom (Table 3). In 2019, the average $\mathrm{BOD}_{5}$ level in the water of Karczemne Lake was ca. $7.0 \pm 3.65 \mathrm{mg} \mathrm{O}_{2}$ $\mathrm{L}^{-1}$, while in the surface water of Klasztorne Małe, it was ca. $7.5 \pm 2.80 \mathrm{mg} \mathrm{O}_{2} \mathrm{~L}^{-1}$, and at the bottom, the average $\mathrm{BOD}_{5}$ level was $41.0 \pm 21.02 \mathrm{mg} \mathrm{O}_{2} \mathrm{~L}^{-1}$ (Table 3).

In 2013, the average Secchi disc visibility in Karczemne Lake was $0.3 \pm 0.15 \mathrm{~m}$ and the chlorophyll-a level was $84.3 \pm 41.4 \mu \mathrm{g} \mathrm{L}^{-1}$. In Klasztorne Małe Lake, the mean Secchi disc visibility was $0.6 \pm 0.35 \mathrm{~m}$ and the chlorophyll-a level was $45.0 \pm 16.8 \mu \mathrm{g} \mathrm{L}{ }^{-1}$. In 2013, the average Secchi disc visibility in Karczemne Lake was $0.3 \pm 0.15 \mathrm{~m}$ and the chlorophyll-a content was $84.3 \pm 41.4 \mu \mathrm{g} \mathrm{L}^{-1}$. In Klasztorne 
Małe Lake, the mean Secchi disc visibility was $0.6 \pm 0.35 \mathrm{~m}$ and the chlorophyll-a content was $45.0 \pm 16.8 \mu \mathrm{g} \mathrm{L}^{-1}$ (Table 3).

In 2019, the average Secchi disc visibility in Karczemne Lake was $0.35 \pm 0.19 \mathrm{~m}$ and the chlorophyll-a level was $116.1 \pm 51.2 \mu \mathrm{g} \mathrm{L}^{-1}$. In Klasztorne Małe Lake, the mean Secchi disc visibility was $0.6 \pm 0.26 \mathrm{~m}$ and the chlorophyll-a level was $82.1 \pm 46.9 \mu \mathrm{g} \mathrm{L}^{-1}$.

\section{Discussion}

\subsection{Nutrient Content of the Water of the Study Lakes and Their Influence on Primary Production and Buffer Capacity Indicators}

The raw domestic and storm sewage entering Karczemne and Klasztorne Małe lakes caused their degradation, defined as hypertrophy. After 60 years of sewage discharge (2019), extremely high concentrations of phosphorus and nitrogen compounds, similar to those found in diluted wastewater, were observed in the lakes (Table 3). A reflection of the very high water fertility of both lakes are the mass blooms of phytoplankton, which are dominated by cyanobacteria ( $65 \%$ of the total phytoplankton composition in Karczemne Lake and $86 \%$ of the total phytoplankton composition in Klasztorne Małe Lake). In both lakes, potentially toxic species of cyanobacteria, such as Microcystis aeruginosa, Aphanizomenon flos-aquae, and Planktothrix agardhii, were noted [39]. It is well known that primary production processes are accompanied by an increase in the water $\mathrm{pH}$ above 8.30 [40-42]. When sewage discharge to Karczemne and Klasztorne Małe lakes began, the increased nutrient concentrations of the water probably promoted intensive photosynthesis, which resulted in phytoplankton blooms, but the $\mathrm{pH}$ of the surface water layers did not exceed 8.70 (Figure 2). As a result of long-term sewage inflow, organic matter production processes have significantly intensified. In 2019, in the polymictic Karczemne Lake, from June to September, the $\mathrm{pH}$ of all water columns exceeded 10.0. On the other hand, in the meromictic Klasztorne Małe Lake, the $\mathrm{pH}$ of the surface water layers oscillated around 9.5.

According to Kusakabe et al. [43] and Zegan and Enache [44], during photosynthesis, free carbon dioxide is depleted, and the chemical equilibrium is shifted between the various calcium carbonate forms present in water. Acid carbonate breaks down with the evolution of $\mathrm{CO}_{2}$ [45], while the neutral carbonate produced tends to precipitate because it is almost 1000 times less soluble than $\mathrm{Ca}\left(\mathrm{HCO}_{3}\right)_{2}$. The effect of these changes is an increase in the water $\mathrm{pH}$ [35]. The water $\mathrm{pH}$ values recorded in 2019 in both the studied lakes were typical for degraded lakes [46,47]. In the shallow, polymictic Karczemne Lake, the $\mathrm{pH}$ was higher, which indicates more intensive production processes than in the bradymictic Klasztorne Małe Lake. This situation is associated with the polymictic type of the water dynamics in this lake, that is, the constant circulation and rotation of nutrient compounds. In one growing season, nutrients are taken up by phytoplankton for photosynthesis, and after death of the algae, cells are quickly released in the processes of destruction and can again participate in the biogeochemical cycle [48]. In polymictic lakes, the rate of organic matter decomposition is high due to the convenient high water temperature. In meromictic lakes, some of the biogenic and organic matter are trapped in hypolimnion waters and do not return to circulation. In the bottom water layers of Klasztorne Małe Lake, organic matter decomposition processes occurred (a water temperature of approximately $\left.4^{\circ} \mathrm{C}\right)$, as evidenced by the increase in the carbon dioxide concentration and decrease in $\mathrm{pH}(6.85-7.38)$ (Figure 2).

\subsection{Circulation of Calcium and Magnesium in the Studied Lakes' Water and Biological Water Decalcification}

The research showed that the average calcium and magnesium concentrations noted in the water of both lakes were high, characteristic of water with a clear impact of anthropopressure. Marszelewski [49] emphasized that in natural water, without anthropogenic changes in the catchment, the calcium to magnesium ratio ranges from 2:1 to 4:1. In the polymictic Karczemne Lake, this ratio was many times higher and varied from 0.9:1.0 to 24.2:1.0, and in Klasztorne Małe Lake, it varied between 1.4:1.0 and 22.2:1.0. This confirms the clear impact of sewage discharge on the lake water 
chemistry. Calcium and magnesium in water undergo various processes, and among others, they are taken up by the plant or animal organisms living in a given ecosystem. As reported by Koschel et al. [50] and Bodzek et al. [51], calcium is absorbed by algae because it is an important building block of cell walls and a component of enzymes, and it participates in the processes of absorbing and accumulating other components from water. In addition, $\mathrm{CO}_{2}$ is produced from calcium carbonate during intensive production processes. The chemical balance between the various forms of calcium carbonate present in water is shifted. Bicarbonate decomposes and neutral carbon sinks to the bottom and settles on the surface of leaves of aquatic plants, thereby forming $\mathrm{CaCO}_{3}$ shells. The calcite entering the water of the hypolimnion, where it dissolves in the presence of $\mathrm{CO}_{2}$, changes into calcium bicarbonate, and some $\mathrm{CaCO}_{3}$ settles at the bottom. This process is called biological water decalcification. The alkalinity also has a close relationship with the biological water decalcification process. The alkalinity of water is associated with the presence of calcium and magnesium carbonates and bicarbonates. Where intensive photosynthesis occurs and $\mathrm{CO}_{2}$ is produced from bicarbonate, the alkalinity is reduced. This phenomenon occurred in the thermally layered Klasztorne Małe Lake. In the reservoir during the growing season, a decrease in calcium concentration and alkalinity in the surface water layers and an increase in calcium concentration at the bottom were noted (Figure 4). In Karczemne Lake, despite intensive photosynthesis, the calcium content and alkalinity were similar throughout the whole water column due to constant circulation (Figure 4). Diurnal fluctuations in metals have been observed in rivers by Rudall and Jarvis [52] and in streams by Nimick et al. [53]. The authors suggested that metals exhibit the most pronounced cyclicity, with concentrations increasing during the night and decreasing during the day. This trend is the inverse of the $\mathrm{pH}$ and temperature observations, which are thought to be the predominant drivers behind cyclicity. The photosynthetic reactions of biomass and algae can alter the $\mathrm{pH}$, therefore promoting hydrous metal oxide precipitation during the day, which consequently produces divalent cations. This mechanism may be supported by the direct uptake of metals by algae and other biogeochemical reactions. Calcium and magnesium may be bound in bottom sediments. According to Grochowska [54], the amount of binding of these elements in bottom sediments depends on the molar ratio of $\mathrm{Ca}$ to $\mathrm{Mg}$. The binding of calcium and magnesium in sediments occurs when the molar ratio of $\mathrm{Ca}$ to $\mathrm{Mg}$ is lower than 1.5. According to Koschel et al. [50] and Danen-Louwerse et al. [55], the binding process of calcium and magnesium carbonate occurs most intensively in hard waters. In the research of Karczemne and Klasztorne Małe lakes, it was found that the processes of calcium and magnesium binding in sediments did not occur. In Karczemne Lake, the water $\mathrm{pH}$ value was conducive to the binding of calcium and magnesium in the sediments, but the molar ratio of these elements was 15 times higher than 1.5, which prevented sediment binding. In Klasztorne Małe Lake, both the reaction in the bottom water layer and the molar ratio of $\mathrm{Ca}$ to $\mathrm{Mg}$ of 20 limited the binding of these metals in the sediments. Kolanek and Kowalski [56] reported that organic compounds are an important factor influencing calcium and magnesium transformation in water. High concentrations of organic matter cause the release of calcium and magnesium from bottom sediments. The sewage inflow to the water of the Karczemne and Klasztorne Małe lakes, along with the sewage inflow containing an extremely high organic matter load, also limited calcium and magnesium binding in the sediments. As previously mentioned, in Karczemne Lake, no vertical water stratification occurred in the presence of calcium, while in Klasztorne Małe Lake, stratification very clearly occurred. In Klasztorne Małe Lake, the decrease in calcium content of the surface water layer corresponded to the increase in chlorophyll-a amount and decrease in Secchi disc visibility. The relationship between calcium concentration and the intensity of production processes was confirmed by the statistical analysis, which revealed a highly significant negative relationship between the calcium content of the water and chlorophyll-a level $\left(\mathrm{y}=-0.0899 \mathrm{x}+56.171, \mathrm{R}^{2}=0.212, \mathrm{R}=-0.460\right.$, and $\left.n=40\right)$. However, no correlation was found between calcium content and Secchi disc visibility. During the growing season in both lakes, a decrease in magnesium amount (included in chlorophyll-a) in the surface waters and an increase in the lower water layers were observed; however, no correlation was found between chlorophyll-a amount and Secchi disc visibility (in decreasing order: $y=-0.0098 x+10.149, R^{2}=0.0038$, 
$\left.\mathrm{R}=-0.062 ; \mathrm{y}=-0.7174 \mathrm{x}+10.827, \mathrm{R}^{2}=0.0377, \mathrm{R}=-0.194\right)$. It can be assumed that biological factors do not directly impact the concentration of magnesium in water. The bottom water layers of these reservoirs were rich in magnesium. Magnesium was released during the decomposition of plant debris falling to the bottom [57-59].

The total hardness noted in the research on both types of lakes indicate good buffer capacity properties. The water of Karczemne Lake can be described as not very hard according to the classification of Dojlido [60] (average total hardness, $2.9 \mathrm{mval} \mathrm{L}^{-1}$, i.e., $146.6 \mathrm{mg} \mathrm{CaCO}_{3} \mathrm{~L}^{-1}$ ), and the water of Klasztorne Małe Lake is moderately hard (average total hardness, $3.32 \mathrm{mval} \mathrm{L}^{-1}$, i.e., $\left.166.1 \mathrm{mg} \mathrm{CaCO}_{3} \mathrm{~L}^{-1}\right)$.

\section{Conclusions}

The analyzed lakes represent ecosystems that have been severely degraded by long-term pollution, mainly by wastewater discharge. Therefore, these polluted lakes developed specific conditions for the functioning of their ecosystems, but the response to pollution depended on the dynamics of the water mass. Studies have shown that the long-term inflow of raw wastewater did not adversely affect the water buffer properties of either lake. Along with the wastewater, carbonate and bicarbonate (e.g., calcium and magnesium, respectively) entered the waters, which resulted in a significant increase in alkalinity. The notable pollution of the lakes affected the circulation of carbonates and hydrocarbons in water and the formation of specific carbonate systems in the growing season. In the polymictic Karczemne Lake, the $\mathrm{pH}$ value of all water columns exceeded 10.0, and in the bradymictic Klasztorne Małe Lake, the $\mathrm{pH}$ of the surface water layers oscillated around 9.5. This situation was caused by intensive photosynthesis. During intensive production processes, $\mathrm{CO}_{2}$ is produced from calcium carbonates. The chemical balance between the various forms of calcium carbonates present in water is shifted. Bicarbonate decomposes and neutral carbon sinks to the bottom and settles on the surface of leaves of aquatic plants, thus forming $\mathrm{CaCO}_{3}$ shells. The calcite entering the water of the hypolimnion, where it dissolves in the presence of $\mathrm{CO}_{2}$, changes into calcium bicarbonate, and some $\mathrm{CaCO}_{3}$ settles on the bottom. This process is called biological water decalcification. The alkalinity also exhibits a close relationship with the biological water decalcification process. The water alkalinity is associated with the presence of calcium and magnesium carbonates and bicarbonates. Where intensive photosynthesis occurs and $\mathrm{CO}_{2}$ is produced from bicarbonate, the alkalinity is reduced. This phenomenon was observed in the thermally layered Klasztorne Małe Lake. In the reservoir, during the growing season, a decrease in calcium concentration and alkalinity of the surface water layers and an increase in calcium concentration at the bottom were noted. In Karczemne Lake, despite intensive photosynthesis, the calcium content and alkalinity were similar throughout the whole water column due to constant circulation.

Funding: This research was funded by Kartuzy City Office. The describes studies use the data "Environmental monitoring of tha kartusian lakes complex".

Acknowledgments: The author would like to thank the Kartuzy City Office for funding this study in the frame of the project titled: Complex restoration of lakes: Mielenko, Karczemne, Klasztorne Małe and Klasztorne Duże in Kartuzy (No 18.690.048-500).

Conflicts of Interest: The author declare no conflict of interest.

\section{References}

1. Dybern, B. Water pollution: A problem with global dimensions. Ambio 1974, 3, 139-145.

2. Mateo-Sagasta, J.; Zaden, S.M.; Turral, H. Water Pollution from Agriculture: Global Review; Food and Agriculture Organization of the United Nations: Rome, Italy; International Water Management Institute on behalf of the Water Land and Ecosystems Research Program: Colombo, Sri Lanka, 2017; pp. 1-29.

3. Schwarzenbach, R.P.; Egli, T.; Hofstetter, T.B.; Von gunten, U.; Wehrli, B. Global water pollution and human health. Annu. Rev. Environ. Resour. 2010, 35, 109-136. [CrossRef] 
4. Søndergaard, M.; Jeppesen, E. Anthropogenic impacts on lake and stream ecosystems and approaches to restoration. J. Appl. Ecol. 2007, 44, 1089-1094. [CrossRef]

5. Friese, K.; Schmidt, G.; Carcalho de Lena, J.; Nalini, H.A., Jr.; Zachmann, D.W. Anthropogenic influence on the degradation of an urban lake-The Pampulha reservoir in Belo Horizonte, Minas Gerais, Brazil. Limnologica 2010, 40, 114-125. [CrossRef]

6. Joniak, T.; Jakubowska, N.; Szelag-Wasilewska, E. Degradation of the recreational functions of urban lake: A preliminary evaluation of water turbidity and light availability (Strzeszyńskie Lake, Western Poland). Pol. J. Nat. Sci. 2013, 28, 43-51.

7. Puri, P.J.; Yenkie, K.N.; Rane, D.B.; Meshram, S.U.; Awale, L.S. Surface water (Futela Lake) quality and its pollution load in terms of water of water quality index (WQI). Adv. Appl. Sci. Res. 2015, 6, 15-26.

8. Allrumman, S.A.; El-Kott, A.F.; Kehsk, M.A. Water pollution: Source and treatment. Am. J. Environ. Eng. 2016, 6, 88-98.

9. Grochowska, J.; Brzozowska, R. Influence of different recultivation methods on durability of nitrogen compounds changes in the waters of an urban lake. Water Environ. J. 2015, 29, 228-235. [CrossRef]

10. Liu, W.; Wang, S.; Zhang, L.; Ni, Z. Water pollution characteristics of Dianchi Lake and the course of protection and pollution management. Environ. Earth Sci. 2015, 75, 3767-3780. [CrossRef]

11. Owa, F.W. Water pollution: Source, effects, control and management. Int. Lett. Nat. Sci. 2014, 3, 1-6. [CrossRef]

12. Dunalska, J.; Wiśniewski, G. How we stop the degradation of lakes? Innovative approaches in lake restoration. Ecol. Eng. 2016, 95, 714-722. [CrossRef]

13. Bhat, S.A.; Pandit, A.K. Surface Water Quality Assessment of Wular Lake, A Ramsar Site in Kashmir Himalaye, Using Discriminant Analysis and WQI. J. Ecosyst. 2014, 2014, 724728. [CrossRef]

14. Augustyniak, R.; Grochowska, J.; Łopata, M.; Parszuto, K.; Tandyrak, R.; Tunowski, J. Sorption properties of the bottom sediment of a lake restored by phosphorus inactivation method 15 years after the termination of lake restoration procedures. Water 2019, 11, 2175. [CrossRef]

15. Kremlova, T.A.; Moiseenko, T.I. Evaluation of the buffer capacity of natural lake waters in Western Siberia: Criteria of resistance to acidification. Geochem. Int. 2016, 55, 559-568. [CrossRef]

16. Lacoul, P.; Freedman, B.; Clair, T. Effects of acidification on aquatic biota in Atlantic Canada. Environ. Rev. 2011, 19, 429-460. [CrossRef]

17. Stokes, P.M.; Bailey, R.C.; Groulx, G.R. Effects of acidification on metal availability to aquatic biota with special reference to filamentous algae. Environ. Health Perspect. 1985, 63, 79-87. [CrossRef]

18. Rostern, N.T. The effects of some metals in acidified waters on aquatic organisms. Oceanogr. Fish. 2017, 4, 1-7. [CrossRef]

19. Milero, F.J.; Woosley, R.; DiTrolio, B.; Waters, J. Effect of ocean acidification on the speciation of metals seawater. Oceanography 2015, 22, 77-85. [CrossRef]

20. Moiseenko, T.I.; Gashkina, N.A.; Dinu, M.I.; Kremleva, T.A.; Khoroshavin, V.Yu. Aquatic geochemistry of small lakes: Effects of environment changes. Geochem. Int. 2013, 51, 1031-1148. [CrossRef]

21. Ibanez, J.G. Alkalinity and buffer capacity of water. Environ. Chem. 2008, 6, 28-56. [CrossRef]

22. Futter, M.N.; Valinia, S.; Löfgren, S.; Köhler, S.J. Long-term trends in water chemistry of acid-sensitive Swedish lakes show slow recovery from historic acidification. Ambio 2014, 43, 77-90. [CrossRef]

23. Jury, Ch.P.; Thomas, F.I.M.; Atkinson, M.J.; Toonen, R.J. Buffer capacity, ecosystem feedbecks, and seawater chemistry under global change. Water 2013, 5, 1301-1325. [CrossRef]

24. Grochowska, J.; Brzozowska, R. The influence of different recultivation methods on the water buffer capacity in a degraded urban lake. Knowl. Manag. Aquat. Ecosyst. 2013, 410, 01. [CrossRef]

25. Claidera, K.; Wickett, M.E. Anthropogenic carbon and ocean pH. Nature 2003, 425, 365. [CrossRef]

26. Evans, C.D.; Monteith, D.T.; Reynolds, B.; Clark, J.M. Buffering of recovery from acidification by organic acids. Sci. Total Environ. 2008, 404, 316-325. [CrossRef] [PubMed]

27. Bhateria, R.; Jain, D. Water quality assessment of lake water: A review. Sustain. Water Resour. Manag. 2016, 2, 161-173. [CrossRef]

28. Price, N.N.; Matz, T.R.; Brainard, R.E.; Smith, J.E. Diel variabilityin seawater $\mathrm{pH}$ related to calcification and benthic community structure on coral reefs. PLOS ONE 2011, 6, e20013.

29. Ries, J.B.; Cohen, A.L.; McCorkle, D.C. Marine calcifiers exhibit mixed responses to $\mathrm{CO}_{2}$-introduced ocean acidification. Geology 2009, 37, 1131-1134. [CrossRef] 
30. Erlandsson, M.; Cory, N.; Fölster, J.; Köhler, S.J.; Laudon, H.; Weyhenmeyer, G.; Bishop, K. Increasing dissolved organic carbon redefinesthe extent if surface water acidification and helps resolve a classic controversy. Bioscience 2011, 63, 614-618. [CrossRef]

31. Kondracki, J.A. Regional Geography of Poland, 3rd ed.; PWN: Warsaw, Poland, 2011.

32. Bajkiewicz-Grabowska, E.; Jańczak, J.; Borowiak, D.; Borowiak, M.; Maślanka, W.; Nowiński, K.; Barańczuk, J. The Evaluation of Abiotic Environment after Operation of Phosphorus Inactivation in the Bottom Sediment Using Phoslock®Preparation; Gdańsk University: Gdańsk, Poland, 2006; p. 41.

33. Dunalska, J.A.; Grochowska, J.; Wiśniewski, G.; Napiórkowska-Krzebietke, A. Can we restore badly degraded urban lakes? Ecol. Eng. 2015, 82, 432-441. [CrossRef]

34. Januszkiewicz, T.; Jakubowska, Ł. Hydrochemical tests of the Klasztorne Lake as a sewage receiver. Work. Inst. Water Manag. 1964, 5, 43-81.

35. Withanachchi, S.S.; Ghambashidze, G.; Kunchulia, I.; Uruschandze, T.; Ploeger, A. Water quality in Surface water: A preliminary assessment of heavy metal contamination of the Mashavera River, Georgia. Int. J. Environ. Res. Public Health 2018, 15, 621. [CrossRef] [PubMed]

36. American Public Health Association. Standard Methods for Examination Water and Wastewater; American Public Health Association: Washington, DC, USA; AWWA: Denver, CO, USA; WPCF: Panama City Beach, FL, USA, 1999.

37. Hermanowicz, W.; Dożańska, W.; Dojlido, J.; Koziorowski, B.; Zerbe, J. Physico-Chemical Study of Water and Wastewater; Arkady: Warsaw, Poland, 1999.

38. Tibco Software Inc. STATISTICA version 13.0. 2018. Available online: https://www.tibco.com/resources/ product-download/tibco-statistica-trial-download-windows (accessed on 5 June 2018).

39. Napiórkowska-Krzebietke, A. Phytoplankton Studies in the Kartuzy Lakes Complex, Unpublished Data. 2019.

40. Franchini, F.; Lepori, F.; Bruder, A. Improving estimates of primary production in lakes: A test and a case study from peri-alpine lake (Lake Lugano). Inland Waters 2017, 7, 77-87. [CrossRef]

41. Wilson, J.; Abboud, S.; Bemon, J.M. Primary production, community respiration, and net community production along oxygen and nutrient gradients: Environmental controls and biogeochemical feedbecks within and across "Marine lakes". Front. Mar. Sci. 2017, 4, 12. [CrossRef]

42. Tanabe, Y.; Hori, M.; Mizuno, A.N.; Osono, T.; Uchida, M.; Kudoh, S.; Yamamuro, M. Light quality determines primary production in nutrient-poor small lakes. Sci. Rep. 2019, 9, 1-8. [CrossRef]

43. Kusakabe, M.; Tanyileke, G.Z.; McCord, S.A.; Schladow, S.G. Recent pH and $\mathrm{CO}_{2}$ profiles at Lakes Nyos and Monoun, Cameroon: Implications for the degassing strategy and its numerical simulation. J. Volcanol. Geotherm. Res. 2000, 97, 241-260. [CrossRef]

44. Zagan, S.; Enache, I. Pollution degree of Tabacarie Lake in 2009. In Proceedings of the 3rd International Conference on Environmental and Geological Science and Engineering, Brasov, Romania, 24-26 September 2009; pp. 132-136.

45. Håkanson, L.; Blenckner, T.; Bryhn, A.C.; Hellström, S.S. The influence of calcium on the chlorophyll-Phosphorus relationship and lake Secchi depths. Hydrobiologia 2005, 537, 111-123. [CrossRef]

46. Macklin, P.A.; Suryaputra, I.G.N.A.; Maher, D.T.; Santos, I.R. Carbon dioxide dynamic in a lake and a reservoir on a tropical Island (Bali, Indonesia). PLoS ONE 2018, 13, e0198678. [CrossRef]

47. Balmer, M.B.; Downing, J. Carbon dioxide concentrations in eutrophic lakes: Undersaturation imples atmospheric uptake. Inland Waters 2011, 1, 125-132. [CrossRef]

48. Kazanjian, G.; Flury, S.; Attermeyer, K.; Kalettka, T.; Kleeberg, A.; Premke, K.; Köhler, J. Primary production in nutrient-rich kettle holes and consequence for nutrient and carbon cycling. Hydrobiologia 2017, 806, 77-93. [CrossRef]

49. Marszelewski, W. Changes in Abiotic Conditions in the Lakes of North-Eastern Poland; Nicolaus Copernicus University: Torun, Poland, 2005.

50. Koschel, R.; Benndorf, J.; Proft, G.; Recknagel, F. Calcite precipitation as a natural control mechanism of eutrophication. Arch. Hydrobiol. 1983, 98, 380-408.

51. Bodzek, D.; Janoszka, B.; Tyrpień, K.; Wielkoszyński, T. Content of calcium and magnesium compounds in selected waters and sewage sludge of Upper Silesia. Environ. Prot. 1998, 4, 17-19.

52. Rudall, S.; Jarvis, A.P. Diurnal fluctuation of zinc concentration in metal polluted rivers and its potential impact on water quality and flux estimates. Water Sci. Technol. 2011, 65, 164-170. [CrossRef] [PubMed] 
53. Nimick, D.A.; Gammons, Ch.H.; Cleasby, T.E.; Madison, J.P.; Skaar, D.; Brick, Ch. Diel cycles in dissolved metal concentrations in streams: Occurrence and possible causes. Water Resoures Res. 2003, 39, 2-17. [CrossRef]

54. Grochowska, J. Circulation of Selected Macroelements and Biogenic Elements in the River-Lake System on the Example of the Upper Pasteka; Committee of Environmental Engineering of the Polish Academy of Sciences: Lublin, Poland, 2015; p. 122.

55. Danen-Louwerse, H.J.; Lijklema, L.; Coenraats, M. Coprecipitation of phosphate with calcium carbonate in lake Veluwe. Water Res. 1995, 29, 1781-1785. [CrossRef]

56. Kolanek, A.; Kowalski, T. Impact of biochemical processes on the concentration of calcium and magnesium compounds in waters. Environ. Prot. 2001, 1, 17-21.

57. Potasznik, A.; Szymczyk, S. Magnesium and calcium concentrations in the surface water and bottom deposits of a river-lake system. J. Elem. 2015, 20, 677-692. [CrossRef]

58. Bbalali, S.; Hoseini, S.A.; Ghorbani, R.; Kordi, H. Relationships between nutrients and chlorophyll a concentration in the international Alma Gol Wetland, Iran. J. Aquac. 2013, 4, 1-5. [CrossRef]

59. Cheng, C.; Wei, Y.; Sun, X.; Zhou, Y. Estimation of chlorophyll a concentrations in Turbid Lake using spectral smoothing andderivative analysis. Int. J. Environ. Res. Public Health 2013, 10, 2979-2994. [CrossRef]

60. Dojlido, J.R. Surface water chemistry. Econ. Environ. Białystok 1995, 212.

(C) 2020 by the author. Licensee MDPI, Basel, Switzerland. This article is an open access article distributed under the terms and conditions of the Creative Commons Attribution (CC BY) license (http://creativecommons.org/licenses/by/4.0/). 